\title{
ラージエディシミュレーションによるストリップ キャスター溶鋼プール内流動の数值解析
}

\author{
梶原 伸治*·大西 邦彦*
}

Numerical Analysis on Fluid Dynamic Phenomena in a Strip Caster Mold by L.E.S.

Shinji KaJIWARA and Kunihiko ONISHI

Synopsis : This report presents the simulation results of flow patterns of liquid metal in a twin roll strip caster. To analyze the velocity field in liquid pool, the influence of the nozzle flow and free surface were considered. The large eddy simulation - L.E.S.—-model was applied to handle the turbulence of flow. The fluctuation of the fluid was measured using the full size water model test apparatus as well. The influence of nozzle flow on the flow pattern was clarified. In the pool the fluctuation of flow depends on casting speed, submerged nozzle type, and so on. The fluctuation of flow changes with the hole type of submerged nozzle.

Key words: strip caster; numerical analysis; large eddy simulation; flow pattern; liquid pool; water model; free surface; twin roll.

\section{1. 緒言}

近年，Near Net Shape プロセスの研究開発が活発に行わ れている。その中のひとつに双ロール式ストリップキャス ターがある1)。ここに，ストリップキャスターの模式罒を Fig. 1に示す。このストリップキャスターは，溶鋼より直 接 $5 \mathrm{~mm}$ 厚以下の薄板材を連続的に鋳造するプロセスであ り，鋳片は熱間圧延されることなく冷間圧延され，製品と なる。この装置が実用化されれば，現在の大型スラブ連続 鋳造機および熱間圧延機が不要となり，工程を大幅に短 縮·簡略化でき，単に，製造コストを低減できるばかりで なく，より多くの効果が期待されている2)。しかしながら， このプロセスでは最終製品までの圧延比が小さいため, 最 終製品の光沢むらの防止や板厚偏差の防止などの問題か ら, 凝固シェルを均一にすることが重要である。この凝固 シェルの均一化のためには，ロール面上の流れのむらを防 止する必要がある。これまで，著者らは水モデル実験等の 実験的手法によって明らかにされた溶鋼プール内流動につ

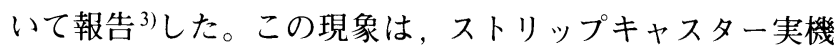
では，周期的な湯面レべル変動となって現れている。また， 従来型の連続鋳造機のモールド内において, 鋳型内の流れ は非対称流れになり易く，周期的に循環流が移動し，流動 の変動が生じていることも報告されている4-6)。この流動 の変動は，実機サイズの水モデル実験機でも観察され，浸 漬ノズル形状に起因するもの ${ }^{7-10)}$, 流量調整のためのスラ イディングノズルによるものなどが考えられている ${ }^{11) 。 し ~}$ かし, これまで, 流れの変動を解析的に取り上げた例は少
ない ${ }^{12,13)}$

一方，八ードウェア・ソフトウェアの進歩によって，数 值流体解析はめざましい進歩をとげ，材料プロセシングに おいても様々に利用されており，ストリップキャスタ一溶 鋼プール内流れについて, 鋳型内流動の解析例の報告は多 (14-17)。しかし，これらの解析ではレイノルズ平均をとっ たものはある ${ }^{18)}$ が, ストリップキャスターのモールド内で 生じるような乱流の非定常計算について検討したものはな い。

そこで本報では, Large Eddy Simulation ${ }^{19}$ (以下L.E.S.と 略す）によりストリップキャスター実験機のプール内につ いて，水モデル実験における乱流の非定常計算を行った。 また，実機サイズの水モデル実験を行い，ストリップキャ スタ一実機における流れの特性を調査し，実験結果と比較 することにより，その精度の検討も行った。

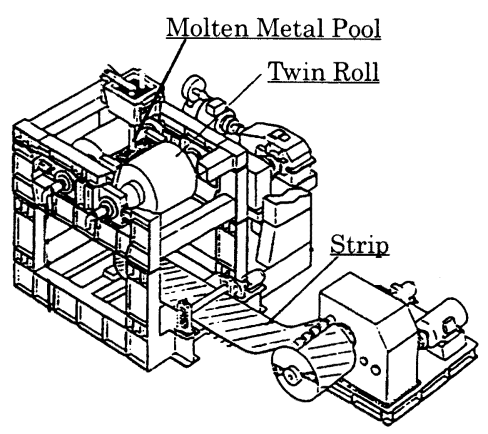

Fig. 1. Schematic view of strip caster. 


\section{2. 数値解析手法}

\section{$2 \cdot 1$ 基礎式 ${ }^{19)}$}

乱流はさまざまな大きさの渦が重ね合わされたものと考 えられる。ある場所 $\mathbf{x}$ のある時刻 $t$ の速度 $f(\mathbf{x}, t)$ は空間的に 変動のある分布になる。そこで, 速度を次式のように時間 平均成分 $\bar{f}(\mathbf{x})$ と変動成分 $f^{\prime}(\mathbf{x}, t)$ の和として表せる。

$$
f(\mathbf{x}, t)=\bar{f}(\mathbf{x})+f^{\prime}(\mathbf{x}, t)
$$

この変動成分 $\bar{f}(\mathbf{x}, t)$ につて, 小スケール渦はモデルを 使い，大スケール渦のみを数值シミュレーションによって 解析する方法がL.E.S.である。そこで，大スケール渦と小 スケール渦を分けるために次のようにフィルタリングを行 う。そこで, 時間と場の関数 $f(\mathbf{x}, t)$ の局所的な空間平均 $\bar{f}(\mathbf{x}, t)$ はフィルタリング関数 $G\left(\mathbf{x}, \mathbf{x}^{\prime}\right)$ を用いると次式のよう に表される。

$$
\begin{aligned}
\bar{f}(\mathbf{x}, t) & =\int_{\infty} G\left(\mathbf{x}, \mathbf{x}^{\prime}\right) \cdot f\left(\mathbf{x}^{\prime}, t\right) d \mathbf{x}^{\prime} \cdots \cdots \\
G\left(\mathbf{x}_{i}, \mathbf{x}_{i}^{\prime}\right) & =\frac{1}{\Delta_{i}}, \mathbf{x}_{i}-\frac{\Delta_{i}}{2}<\mathbf{x}_{i}^{\prime}<\mathbf{x}_{i}+\frac{\Delta_{i}}{2} \\
& =0, \text { otherwise }
\end{aligned}
$$

式( 3 )は今回用いたTop Hat Filterを示しているが，この フィルタはボックスフィルタとも呼ばれ，区間 $\Delta_{i}$ での単 純平均を用いるものである。 $\Delta_{i}$ はフィルタ幅で格子幅に選 ばれる。これらを $l=1,2,3$ 方向に適用して三次元フィルタ とした。

この式( 2 )であらわされるフィルタリングの操作を連続 の式および非圧縮性 Navier-Stokes式に施したものを次式 に示す。

$$
\begin{aligned}
& \nabla \cdot \overline{\mathbf{u}}=0 \\
& \frac{\partial \overline{\mathbf{u}}}{\partial t}+\nabla \cdot(\overline{\mathbf{u}} \overline{\mathbf{u}}+\mathbf{R})=-\nabla \frac{\bar{p}}{p}+v \Delta \overline{\mathbf{u}}
\end{aligned}
$$

この式( 5 )にフィルタリングによって生ずる大スケール 渦の場に対する見かけの応力テンソル $\mathbf{R}$ が現れるが，スマ ゴリンスキーモデル20)を用いることにより， Reynolds応力 項 $\overline{\mathbf{u}_{i}^{\prime} \mathbf{u}_{j}^{\prime}}$ 以外を小さいものとして無視した。これらによっ

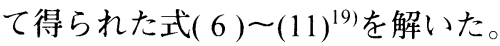

$$
\begin{aligned}
& \frac{\partial \bar{u}_{i}}{\partial x_{i}}=0 \\
& \frac{\partial \bar{u}_{j}}{\partial t}+\frac{\partial\left(\bar{u}_{i} \bar{u}_{j}\right)}{\partial x_{j}}=-\frac{1}{\rho} \frac{\partial \bar{p}}{\partial x_{i}}+v \frac{\partial^{2} \bar{u}_{i}}{\partial x_{j}^{2}}-\frac{\partial R_{i j}}{\partial x_{j}} \\
& R_{i j}=-v_{T} \cdot\left(\frac{\partial \bar{u}_{i}}{\partial x_{j}}+\frac{\partial \bar{u}_{j}}{\partial x_{i}}\right) \\
& v_{T}=(C \cdot \Delta)^{2} \cdot\left(2 \cdot \bar{D}_{i j} \cdot \bar{D}_{i j}\right)^{1 / 2}
\end{aligned}
$$

$$
\bar{D}_{i j}=\frac{1}{2} \cdot\left(\frac{\partial \bar{u}_{i}}{\partial x_{j}}+\frac{\partial \bar{u}_{j}}{\partial x_{i}}\right)
$$

$$
\Delta=\left(\Delta_{1} \cdot \Delta_{2} \cdot \Delta_{3}\right)^{1 / 3}
$$

ここで

$\rho$ : 密度

$v$ : 動粘性係数

$C$ : Smangorinsky 定数 $(=0.1)$

$R_{i j}$ : Reynolds 応力項

$v_{T}$ : 渦粘性係数

$\bar{D}_{i j}$ : 大スケールの流れ場のひずみテンソル

$\Delta$ : フィルタ幅の代表值

である。

\section{$2 \cdot 2$ 境界条件}

境界条件としては次のものを用いた。

上部（流入口）: $\bar{u}=\bar{u}_{\text {in }}$

液面(メニスカス)： Free Surface

ロール面 $\quad: \frac{\partial \bar{p}}{\partial \mathbf{x}_{i j}}=0$

下部（流出口）: $\bar{u}=\bar{u}_{\text {out }}$

ただし，速度に関しては，1/7 乗則 ${ }^{21}$ およよ゙二層モデ ル22)を用いた。また，流入流量と流出流量は同じとした。

\section{3. 計算条件}

\section{$3 \cdot 1$ 計算対象および計算条件}

ストリップキャスターの水モデル実験機を対象にした。 ロール直径は $1200 \mathrm{~mm}$, ロール胴長は $1100 \mathrm{~mm}$, ロール間 隔（鋳片厚さ）は $5 \mathrm{~mm}$, 液面高さは $400 \mathrm{~mm}$ とした。流量 は，ロール速度を $50 \mathrm{~m} / \mathrm{min}$ として， $4.583 \times 10^{-3} \mathrm{~m}^{3} / \mathrm{sec}$ とし た。また, 重力加速度は $9.8 \mathrm{~m} / \mathrm{sec}^{2}$, 計算の時間ステップ は，0.00025秒である。計算開始の 10 秒間を非定常時間と して除外し, 開始 10 秒後を解析時間の 0 秒とした。プログ ラムは, SEA社製の Flow-3Dの内部サブルーチンを改造し たものを用いた。

\section{$3 \cdot 2$ 解析領域および計算メッシュ}

解析領域は，ストリップキャスターの浸漬ノズルおよび 溶鋼プールを対象とし，溶鋼プール内流れに注目した。

\section{$3 \cdot 2 \cdot 1$ 一般座標系による解析}

一般座標系による解析メッシュを Fig. 2に示す。メッ シュ数は, 51 (短辺方向 $) \times 56$ (ロール胴長方向 $) \times 21$ (深 さ方向 $)=59976$ である。また，ノズル部分はノズル形状が 十分に表現できるように配慮した。

\section{$3 \cdot 2 \cdot 2$ 極座標系による解析}

ロールの回転の影響を確認するため，軸対称，1/4断面 における解析も行った。軸対称解析の解析メッシュを Fig. 3 に示す。Fig. 3の奥側がノズルであり，手前側が短辺堰 


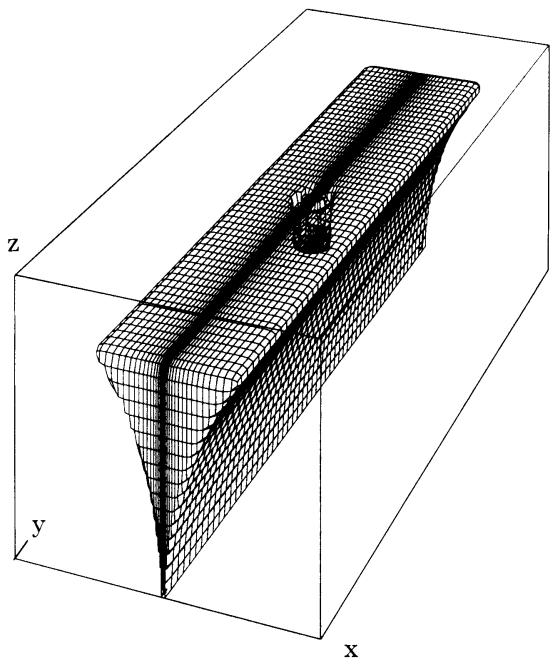

Fig. 2. Mesh arrangement. (General axis)

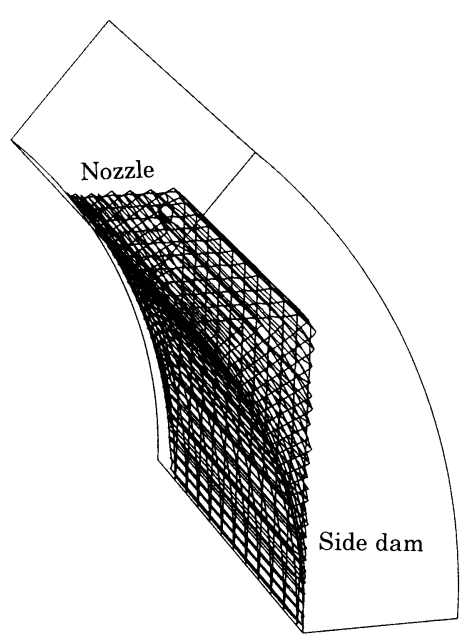

Fig. 3. Mesh arrangement. (Cylindrical axis)

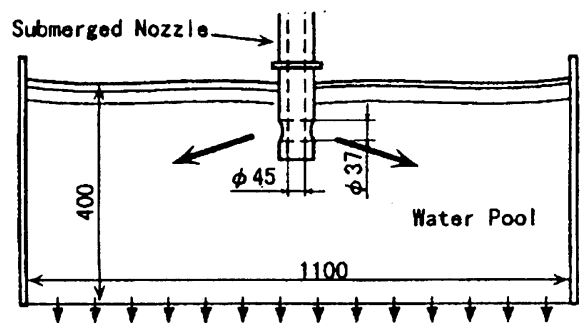

Fig. 4. Schematic diagram of water model apparatus.

である。メッシュ数は, 20 (径方向 $) \times 36$ (回転方向 $) \times 12$ (ロール軸方向) である。この解析では，ロールに接して いる流体の流速をロール回転速度とすることによってロー ル回転が全体流れにおよぼす影響を調べた。ただし，浸漬 ノズルについては, 形状を簡略化し, 対称面から短辺部に 流入させるものにした。

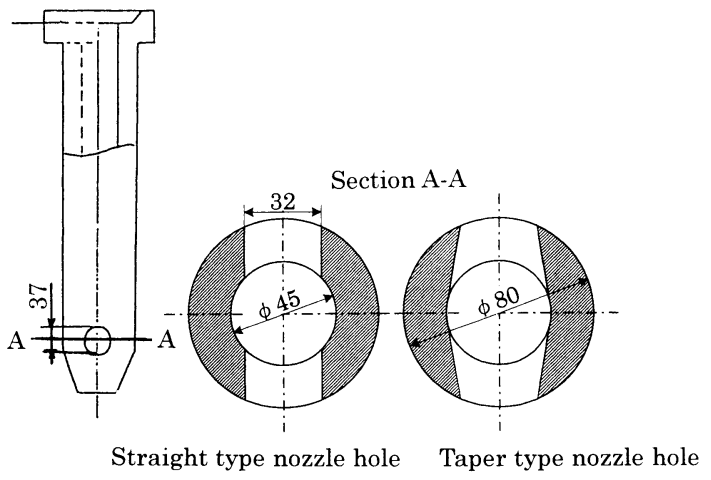

Fig. 5. Schematic view of submerged nozzle.

\section{4. 水モデル実験条件 ${ }^{3)}$}

Fig. 4 に示す実機スケールの水モデル実験機を用い，直 径 $5 \mathrm{~mm}$ のプロペラ式流速計によってロール面上の流速を サンプリング周波数 $50 \mathrm{~Hz}$ で計測を行った。ただし，この 実験装置のロールはアクリル製で固定されている。実験条 件としては, Fig. 5 に示すノズル穴形状がストレートのも のとテーパつきのものの 2 種類，スループットについては， 実機での $30 \mathrm{~m} / \mathrm{min}, 40 \mathrm{~m} / \mathrm{min}, 50 \mathrm{~m} / \mathrm{min}$ に対応した流量の 3 種類について行った。ただし，水モデル実験での実際の流 量はそれぞれ $1.65 \times 10^{-3}, 2.20 \times 10^{-3}, 2.75 \times 10^{-3} \mathrm{~m}^{3} / \mathrm{sec}$ であ る。また，短辺側よりレーザスリットをあて，直径数十ミ クロンの密度 $1060 \mathrm{~kg} / \mathrm{m}^{3}$ のポリスチレン粒子をトレーサと して流れの様子の観察も行った。このレーザスリット観察 の際は, 流量およびその他の条件は解析の条件と同様とし た。

\section{5. 結果}

\section{$5 \cdot 1$ 一般座標系での計算結果}

液面から深さ $100 \mathrm{~mm}$ の位置での水平断面における流動 の樣子を Fig. 6に示す。ただし，0秒における流速べクト ルを Fig. 6(a)に，10秒における流速べクトルを Fig. 6(b)に それぞれ示す。Fig. 6の中央部には円形のノズル底部があ り，2本のロール間でノズル流が生じている。Fig. 6 から 水平方向断面に打いて左右非対称流れが起こっていること がわかる。

また，ロール間中央部での流動挙動の時間変化を Fig. 7 に示す。この図から，垂直断面においても同様に，流動は 非対称な振動挙動を示していることがわかる。

ノズル中心から幅方向に $450 \mathrm{~mm}$, 液面から深さ $100 \mathrm{~mm}$ におけるロール表面付近の流速の経時変化を Fig. 8 に示 す。この四から，ロール方向，短片方向，深さ方向，それ ぞれの流速が約 $0.8 \sim 1$ 秒周期で変動していることがわか る。また，10秒間に流れは短辺方向には約 $1 / 4$ 周期，ロー ル方向および深さ方向には約 $1 / 2$ 周期の流れの変動が見ら 


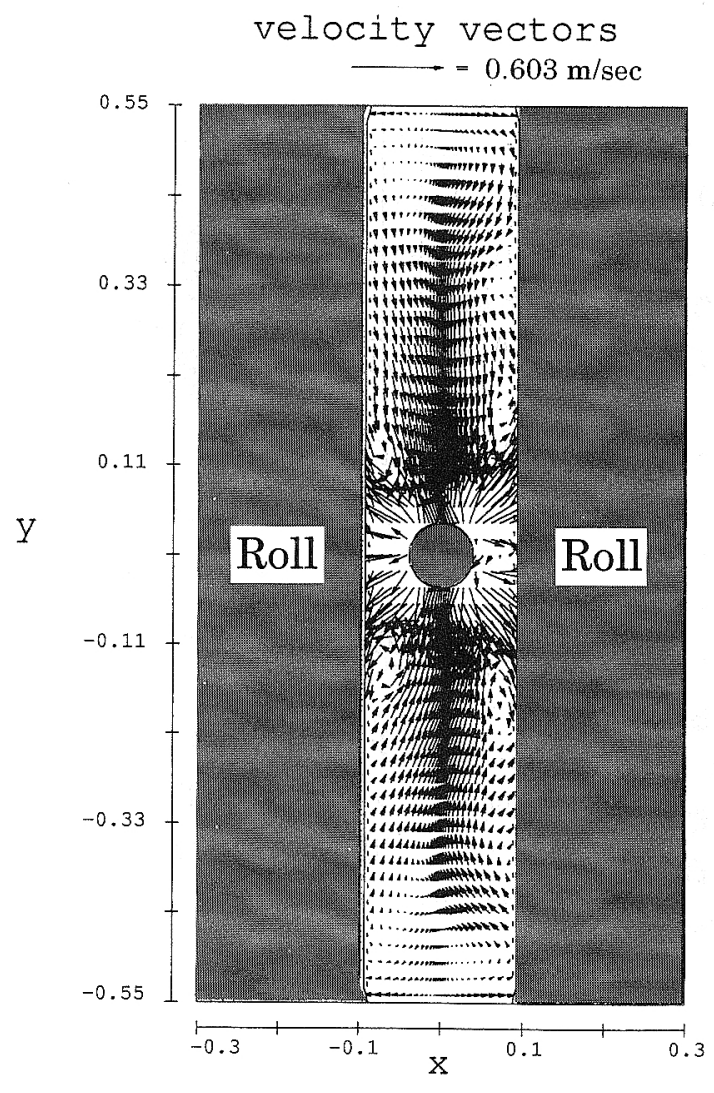

(a) $0.0 \mathrm{sec}$

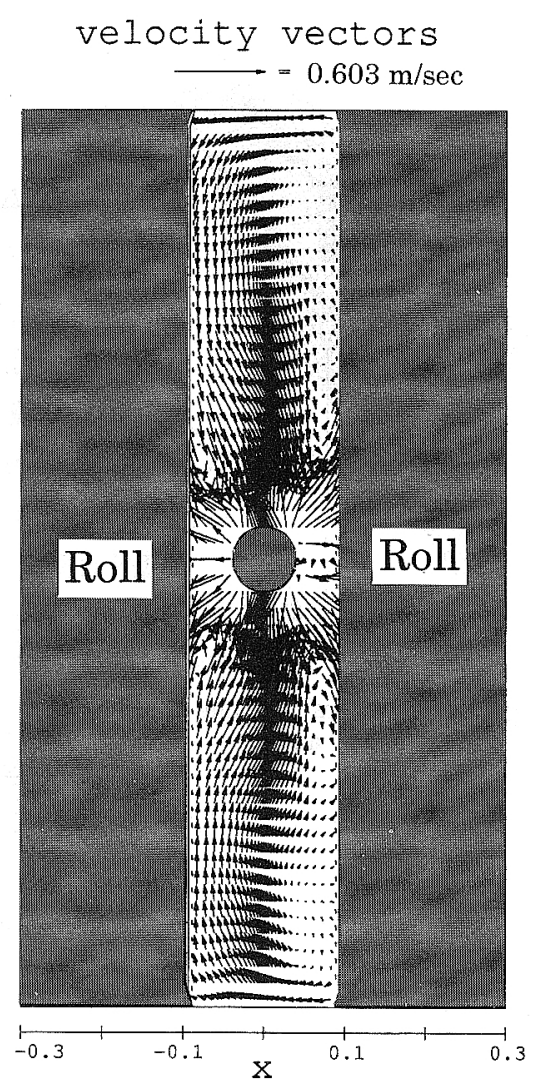

(b) $10.0 \mathrm{sec}$

Fig. 6. Calculated fluid velocities on surface of roll at $100 \mathrm{~mm}$ in depth by general axis.

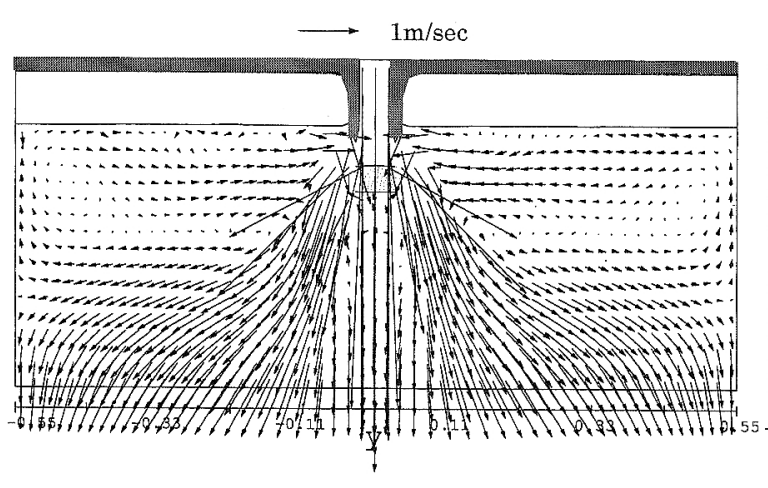

(a) $0.0 \mathrm{sec}$

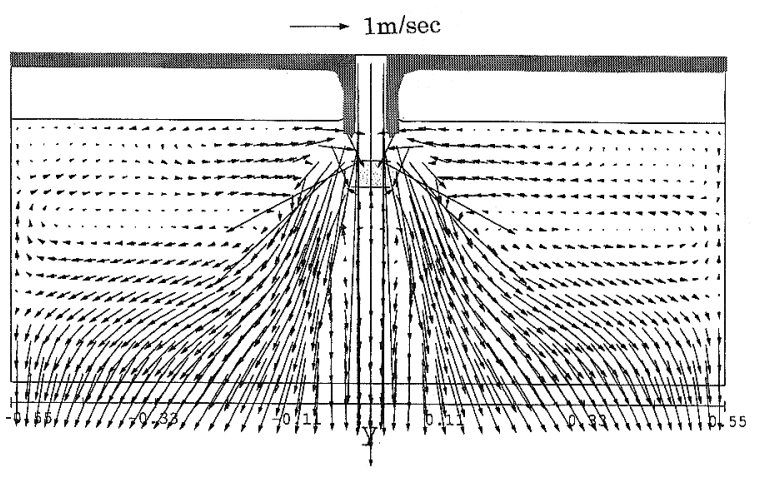

(b) $10.0 \mathrm{sec}$

Fig. 7. Calculated time evolution of fluid velocities at center of twin rolls.

れる。

\section{$5 \cdot 2$ 円筒座標系での計算結果}

円筒座標系での計算結果を Fig. 9 から Fig.11に示す。0秒 におけるノズル中心より幅方向に $450 \mathrm{~mm}$, 短辺堰より $100 \mathrm{~mm}$ の断面での流速分布を Fig. 9に示す。Fig. 9 より， ロール面上の鋳片に相当する場所の流れによってロール間 隔中央対称面に打いて大きな逆流が生じていることがわか る。これら円筒座表系の結果では, 流体の流入の方向を ロール胴長方向としているため, 液面部での流速が大きく なっている。0秒に打ける速度べクトルの透視龱をFig.10 に示す。この図より，一本ノズルでの鋳造ではノズル流は
短辺堰に当たり，降下し，ノズル方向に流れるというよう な大きな流れが生じているがわかる。ノズル中心から $450 \mathrm{~mm}$, 液面からの深さ $100 \mathrm{~mm}$ でのロール表面付近の短 辺方向流速の経時変化を Fig.11に示す。この図より，ロー ル表面流速は, 約 11 秒周期で周期的な変動をしているこ とがわかる。

\section{$5 \cdot 3$ 実験結果}

プロペラ式流速計で計測された流速の計測結果の例を

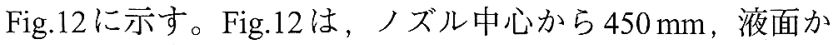
ら深さ $100 \mathrm{~mm}$ に抢けるロール面付近の流速の経時変化で ある。この図より，約 $0.8 \sim 1.0$ 秒周期の比較的周期の短い 


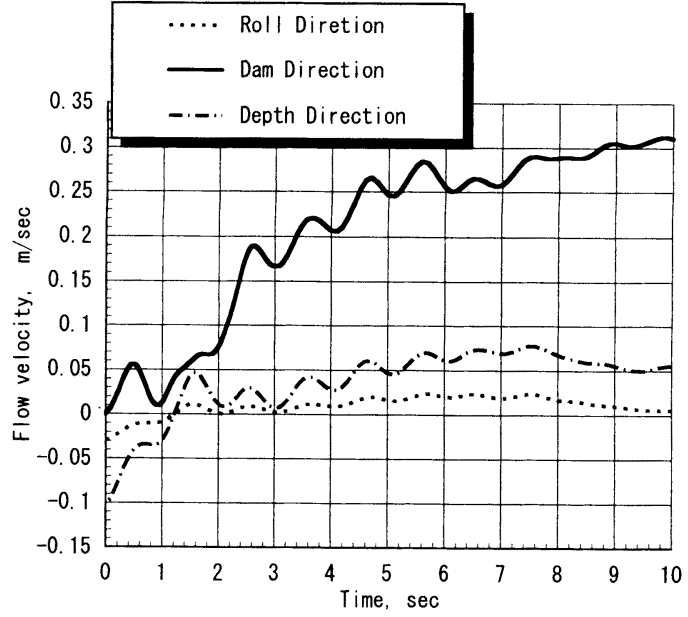

Fig. 8. Fluid velocity of time evolution at $450 \mathrm{~mm}$ from center of nozzle, $100 \mathrm{~mm}$ in depth.

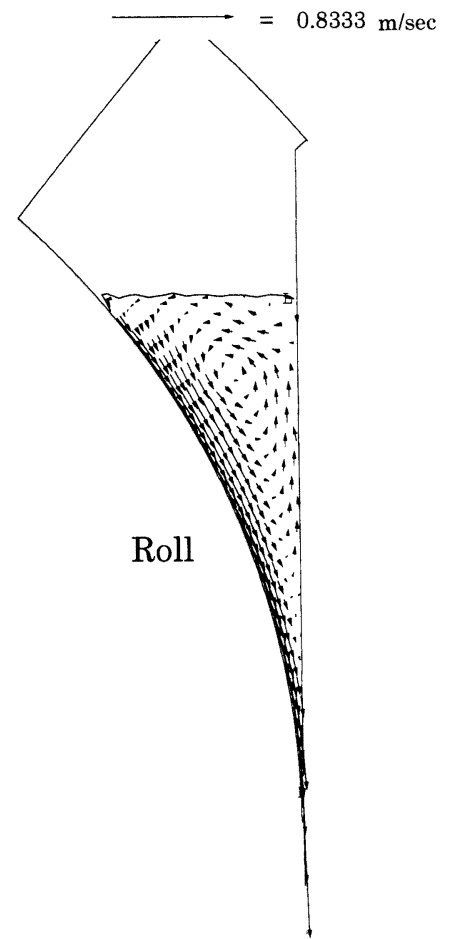

Fig. 9. Fluid velocity vectors at $450 \mathrm{~mm}$ from nozzle.

振動と約 10 秒周期の比較的周期の長い振動の 2 種類の振動 が見られる。ストレートタイプのノズルで計測されたノズ ル中心からの距離と流速の変動幅の関係を Fig.13に示す。 ただし，Fig.13(a)は液面からの深さ $100 \mathrm{~mm}$, Fig.13(b)は液 面からの深さ $150 \mathrm{~mm}$ の計測結果を表している。これらの 困より，ロール表面付近の流速の変動幅は，深さ $100 \mathrm{~mm}$ においてノズルからの距離 $400 \mathrm{~mm}$ ，深さ $150 \mathrm{~mm}$ において ノズルからの距離 $350 \mathrm{~mm}$ で最大となっていることがわか る。

次に，ストレートタイプノズルおよびテーパタイプノズ ルにおけるスループットと流速の変動幅の関係を Fig.14に 示す。Fig.14のスループットとはストリップキャスター実

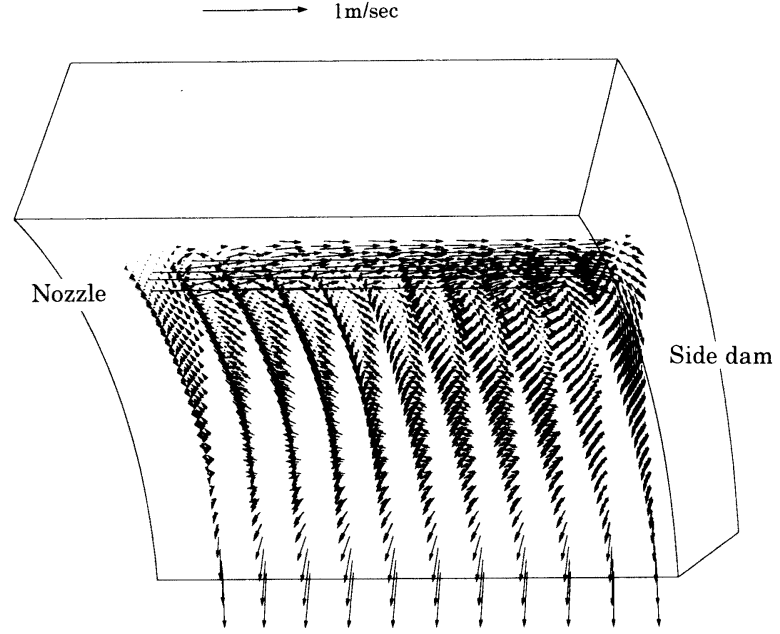

Fig. 10. Perspective fluid velocity vectors of cylindrical axis analysis.

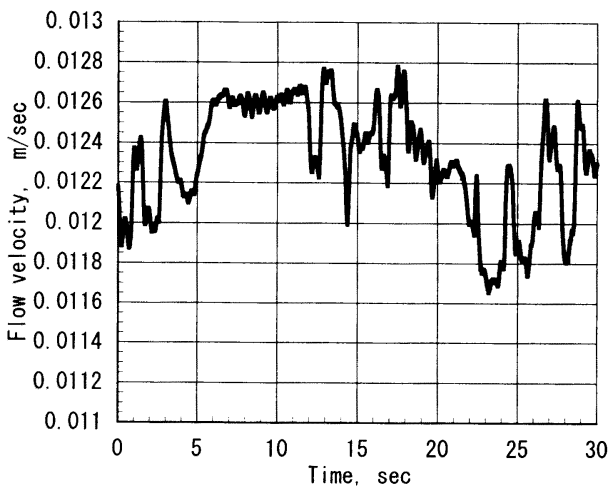

Fig. 11. Calculated fluid velocities on surface of roll at $450 \mathrm{~mm}$ from center of nozzle, $100 \mathrm{~mm}$ in depth by cylindrical axis analysis.

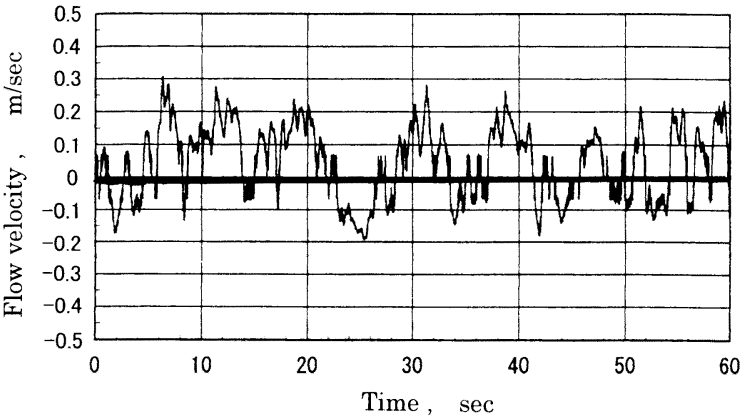

Fig. 12. Measured flow velocity on roll surface at $450 \mathrm{~mm}$ from center of nozzle, $100 \mathrm{~mm}$ in depth.

機における相当鋳造速度であり，実際の注水流量は，例え ば $50 \mathrm{~m} / \mathrm{min}$ の場合は, $50 / 60 \mathrm{~m} / \mathrm{sec}$ (鋳造速度) $\times 1.1 \mathrm{~m}$ (鋳 片幅 $) \times 0.003 \mathrm{~m}$ (鋳片厚み) $=2.75 \times 10^{-3} \mathrm{~m}^{3} / \mathrm{sec}$ である。 Fig.14より鋳造速度が速いほど流動の変動幅も大きいこと がわかる。また， 30〜 $50 \mathrm{~m} / \mathrm{min}$ の鋳造速度においてテーパ タイプのノズルはストレートタイプのノズルよりも流動の 変動幅は小さい。

流れの振動の模式図を Fig.15に示す。レーザスリットに よる流れの変動の様子をFig.16に示す。ただし, Fig.16(a) 


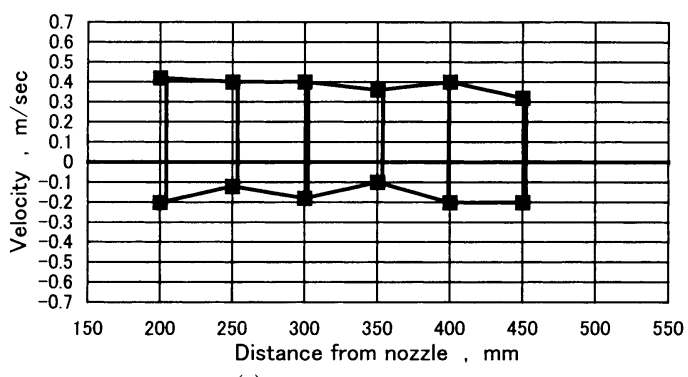

(a) $100 \mathrm{~mm}$ in Depth

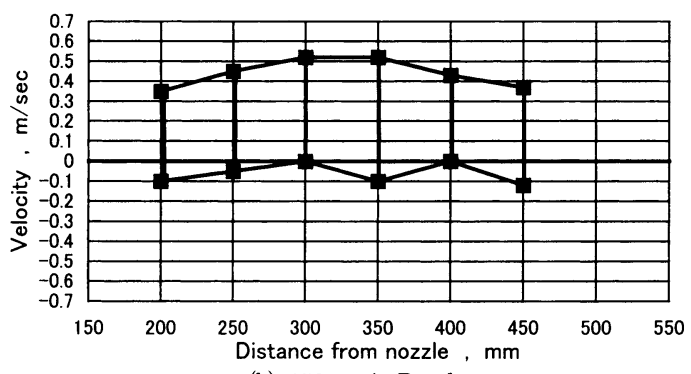

(b) $150 \mathrm{~mm}$ in Depth

Fig. 13. Relation between distance from nozzle and fluctuation of velocity.

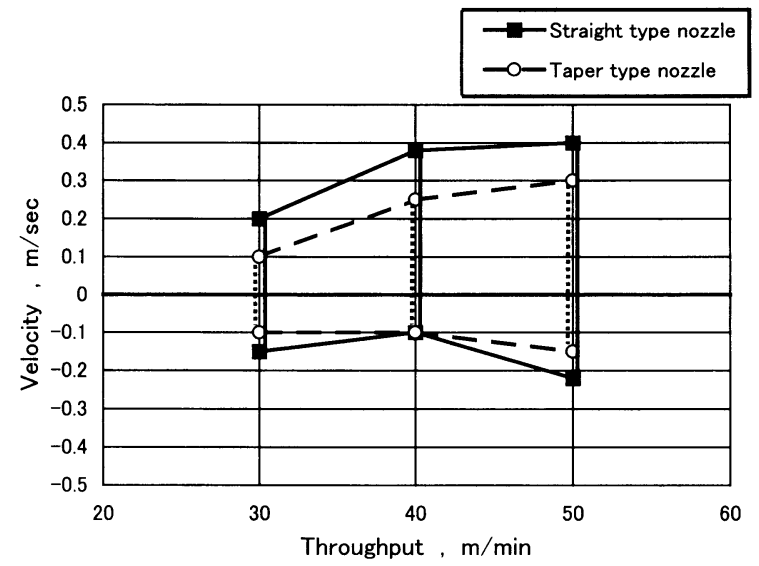

Fig. 14. Relation between throughput and fluctuation of velocity.

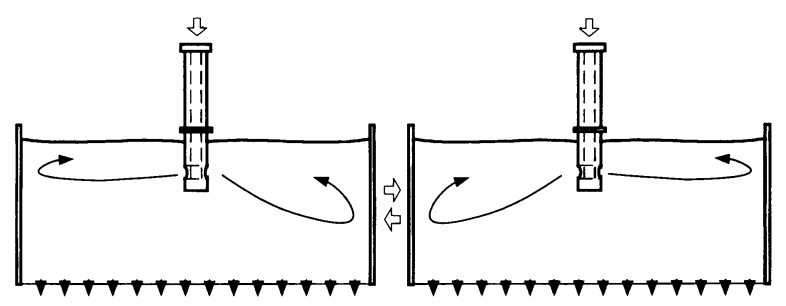

Fig. 15. Schematic view of the main flow pattern in the water model.

はレーザスリットを垂直方向に照射しロール間中央部のも のであり，Fig.16(b)はレーザスリットを水平にあて，液面 より $100 \mathrm{~mm}$ の深さのものである。また，Fig.16(c)には Fig.16(b)の0.125 sec毎の連続写真を示す。0 secにおいて短 辺堰近傍のロール間中央部にトレーサの密集した渦の中心 がみられる。これが，0.125 secで左右に分割し，再び $0.5 \mathrm{sec}$ で1つに合併し，0.75 secで渦が上下に分裂し，
0.875 秒後には合併していることがわかる。これらの観察 によっても流体の振動は, 約 $1 \sim 1.5 \mathrm{~Hz}$ で起こっているこ とがわかった。

\section{6. 考察}

L.E.S.を用いストリップキャスター溶鋼プール内につい て非定常流れの解析を行った結果，プール内は非対称流れ であり，ロール表面流速は約 $1 \sim 1.5 \mathrm{~Hz}$ 扎よび約 10 秒周期 の振動が存在することがわかった。解析は，ロールを固定 させた直交デカルト座標を用いたものとロールの回転を考 慮した極座標系の二種類について行った。その結果の比較 を行ったが, 短辺方向のロール表面流速の振動周期には変 化が見られなかった。つまり，短辺方向の流動の振動周期 には，ロールの回転の影響がないことがわかった。

流れの振動は，渦の中心がノズルより短辺堰方向に移動 するようなアンバランスな流れによるものである。この流 れの変動は水モデル実験機によるロール表面流速の計測に おいても観察された。渦の中心の移動についても，ポリス チレンを用いたレーザスリット観察で確認された。これら 数值解析および水モデル計測ともに液面を自由表面として いるため, 流動の変動は重力影響が大きいと考えられる。

ストリップキャスターのプールの固有振動数を Fig.17に 示す。Fig.17は，次式で示される波動方程式23)をストリッ プキャスター溶鋼プールについて長手方向および短辺方向 の 2 方向について解いた結果である。溶鋼プールの短辺方 向幅は，ロール直径 $1.2 \mathrm{~m}$, 湯面高さ $0.4 \mathrm{~m}$ であるので， $\left\{(1.2 / 2)-\left((1.2 / 2)^{2}-0.4^{2}\right)\right\}=0.305 \mathrm{~m}$ である。

$$
f=\frac{\sqrt{g \cdot k \cdot \tanh k \cdot H}}{2 \cdot \pi} \quad\left(\frac{\pi \cdot n}{l}, n=1,2, \cdots\right)
$$

ここに,

$f$ : スロッシング周波数

$g$ : 重力加速度 $\left(9.8 \mathrm{~m} / \mathrm{sec}^{2}\right)$

$H:$ 溶鋼プール深さ $(0.4 \mathrm{~m})$

$l:$ 溶鋼プール幅 $(1.1 \mathrm{~m}, 0.352 \mathrm{~m})$

$n$ : 振動モード

である。ただし，Fig.17における括弧の前の数字は長手方 向のモードであり，後ろの数字は短辺方向のモードである この結果から，1.5 Hzの振動は，長手方向のモードが 4 , 短辺方向のモードが0であることがわかる。この振動モー ドについては，水モデル実験の結果でも確認された。

次に，流動の振動の大きさについて検討を行う。水モデ ル実験の結果では左右交互の流れの変動はスループットが 少ないほど小さい。これは, Reynolds数の減少により，乱 流度が小さくなった影響であると考えられる。同様に，， ズル吐出口形状の比較で，ストレートタイプよりもテーパ タイプが流動の変動が小さい。これは，ストレートタイプ 


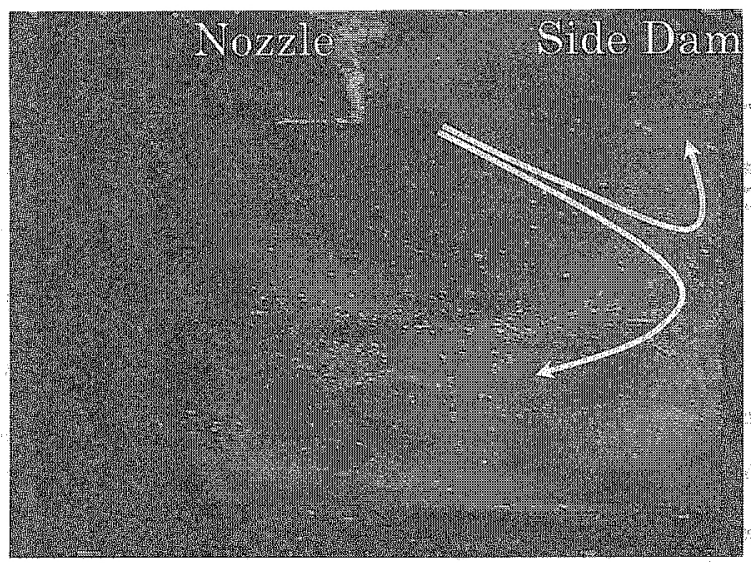

(a) Vertical view

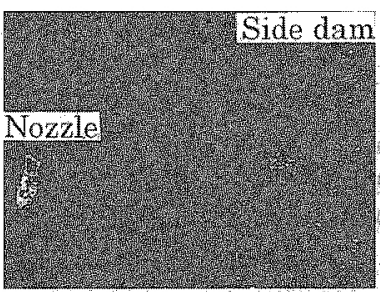

Osec

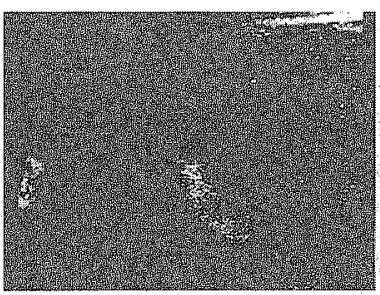

$0.5 \mathrm{sec}$

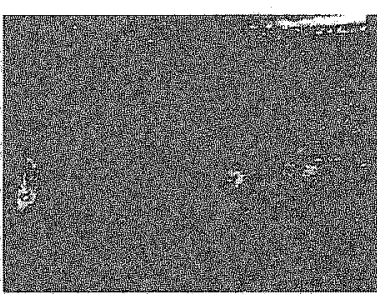

$0.125 \mathrm{sec}$

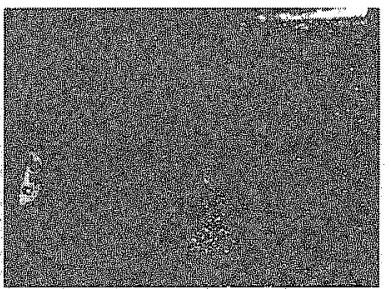

$0.625 \mathrm{sec}$

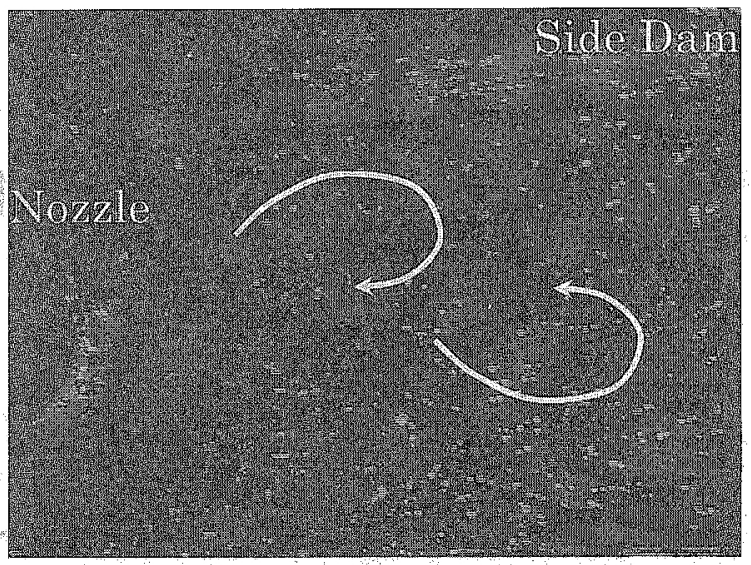

(b) Horizontal view

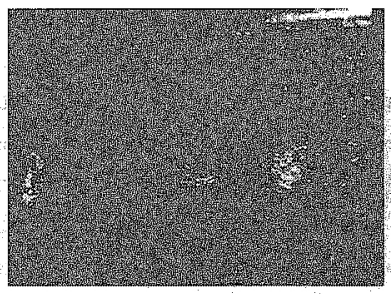

$0.25 \mathrm{sec}$

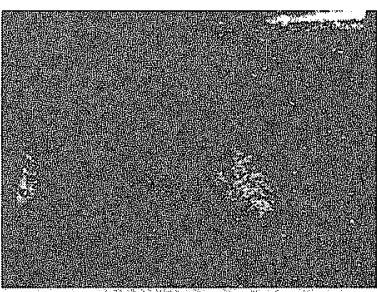

$0.375 \mathrm{sec}$

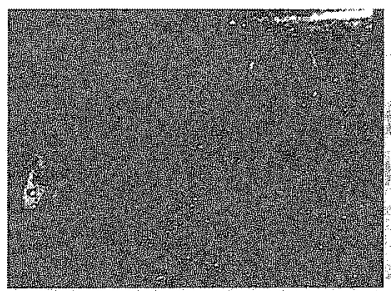

$0.75 \mathrm{sec}$

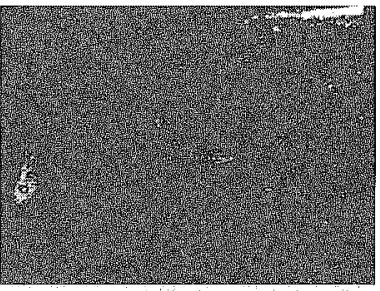

$0.825 \mathrm{sec}$

(c) Sequence photographs at every 0.125 seconds

Fig. 16. Laser slit observation of water flow.

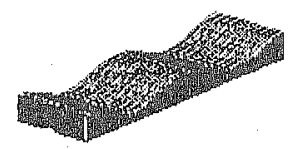

(4.0) $\quad 1.573 \mathrm{~Hz}$

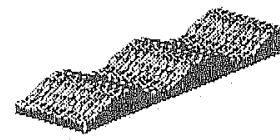

(5, 目) $\quad 1.83 \mathrm{~Hz}$

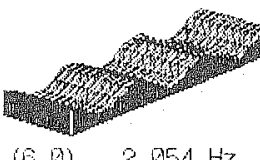

(6) . $)$ 2. $054 \mathrm{~Hz}$

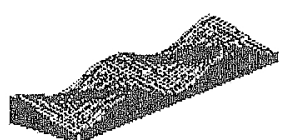

(4.1) $\quad 1.907 \mathrm{~Hz}$

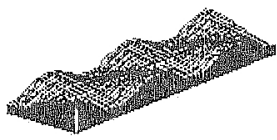

(6., $)$ 2. $875 \mathrm{~Hz}$

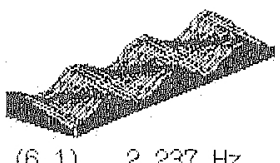

(6.1) 2.297 $\mathrm{Hz}$

Fig. 17. Natural frequency of strip caster pool.

では降下流が吐出口八向かうときの段差で乱流が促進され ることによると予想される。一本ノズルでの鋳造の場合は ノズル吐出流による定常鋳造中の凝固シェルの再溶解学抑 制するため，ノズル開口部は左右幅よりも上下幅を大きく 開口させるとよいことがわかった。ただし，ノズル開口部

が十分に浸漬させるような上下幅である必要がある。

\section{7. 結言}

（1） L.E.S，老用いたストリップキャスター水モデル実 験機のプール内流れての非定常流れ解析を行った。解析は, 一般座標系拉よび極座標系について行った。その結果, 短 辺方向の流れの変動周期にはロール回転の影響がないこと がわかった。

(2) 従来型連続鋳造機で観察された変動の流動がスト リップキャスターにおいても起こっていることが数值解析 および氷モデル実験機において観察された。水モデル実験 機の流れの実測と解析で求められた流れの変動とは, 1.0 1.5 Hzの振動と約 10 秒周期の振動が見られ，よく一致 した。

(3) メニスカスを自由表面として取り扱うことによ り，表面波の影響も取り扱つた。溶鋼プールについて波動 方程式を解いたモード解析の結果, 長手方向のモードが 4 
の場合に $1.57 \mathrm{~Hz}$ の固有振動数を持ち，これが水モデル実 験の観察結果およびロール表面流速計測結果とよく一致し た。

（4）解析結果および水モデル実験の結果より，流れの 振動は渦の中心がノズルより短辺堰方向に移動するような アンバランスな流れによるものであることがわかった。

\section{記 号}

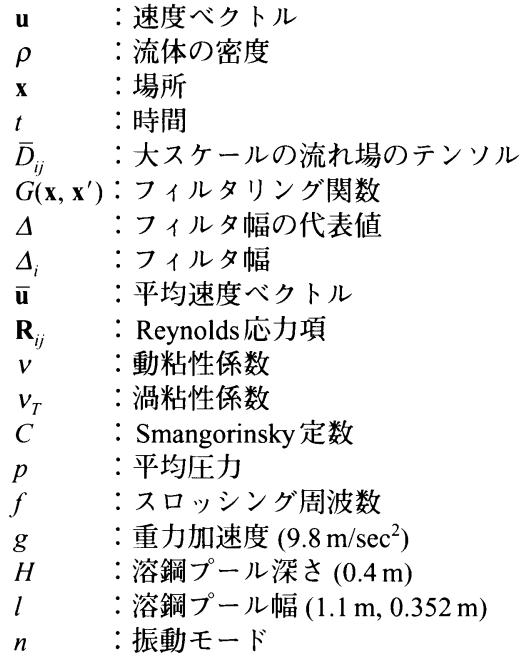

\section{文献}

1) 大西邦彦：薄板エコプロセスの現状と課題, 創形創質工学部
会編，日本鉄鋼協会，東京，(1998), 29.

2 ) C.Hendricks: MPT Int., 3 (1995), 42.

3 ) S.Kajiwara, K.Onishi, M.Haitani, T.Kawasaki and K.Nomura: CAMP-ISIJ, 10 (1997), 250.

4 ) K.Kawakami: Tetsu-to-Hagané, 67 (1981), 40.

5) A.R.Bucher: Stahl Eisen, 117 (1997), 47.

$6)$ H.Tozawa, S.Idogawa, S.Nakato and K.Sorimachi: CAMP-ISIJ, 9 (1996), 604.

7 ) T.A.Honeyands and J.Herberson: CAMP-ISIJ, 7 (1994), 317.

8 ) T.A.Honeyands and J.Herberson: Steel Res., 66 (1995), 287.

9 ) J.Kubota, H.Ozawa, Y.Yamaoka and M.Suzuki: CAMP-ISIJ, 5 (1992), 1245.

10) D.Gupta and A.K.Lahiri: Metall. Mater. Trans. B, 27B (1996), 757.

11) K.Sasai, H.Yamamura, N.Tsutsumi, Y.Mizukami and H.Esaka: CAMP-ISIJ, 5 (1992), 223.

12) I.Sawada, K.Shigematsu, Y.Hori and M.Yamazawa: CAMP-ISIJ, 5 (1992), 1247.

13) I.Sawada, Y.Kishida, K.Okazawa and H.Tanaka: Tetsu-to-Hagané, 79 (1992), 160

14) T.Saito and H.Hojo: Metall. Mater. Trans. B, 20B (1989), 381.

15) M.Shiomi, K.Mori and K.Osakada: Trans. Jpn. Soc. Mech. Eng., 61C (1995), 1796.

16) H.Sanari and T.Inoue: Trans. Jpn. Soc. Mech. Eng., 56A (1990), 591.

17) H.Sanari and T.Inoue: Trans. Jpn. Soc. Mech. Eng., 56A (1990), 684.

18) H.Murakami, M.Hansen and R.I.L.Guthrie: CAMP-ISIJ, 6 (1993), 1135.

19）保原 充, 大宮司久明：数值流体力学一基礎と応用, 東京大 学出版会, 東京, (1992), 213 .

20) J.Smagorinsky: Mon. Weather Rev., 91 (1963), 99.

21) S.Murakami, S.Kato and Y.Kondo: Seisan-Kenkyu, 43 (1992) 37.

22) Y.Morinishi and T.Kobayashi: Trans. Jpn. Soc. Mech. Eng., 55B (1989), 615 .

23）海老原熊雄: 流体力学ハンドブック, 日本流体力学会編, 丸 善, 東京, (1987), 720 